\title{
Doksa Penerbit Kristal Multimedia dalam Menerbitkan Ulang Buku-Buku Kaba
}

\author{
The Doxa of Kristal Multimedia Publisher in Republishing Kaba Books
}

\author{
Nur Ahmad Salman Herbowo ${ }^{1, *}$, Khairil Anwar ${ }^{2}$, dan Ferdinal $^{3}$ \\ ${ }^{1,2,3}$ Magister Sastra, Fakultas Ilmu Budaya, Universitas Andalas \\ 1,* Corresponding email: salman.herbowo@gmail.com \\ ${ }^{2}$ Email: khairrilanwar@gmail.com \\ ${ }^{3}$ Email: ferdina109@yahoo.com
}

Received: 21 January 2021 Accepted: 17 February 2021 Published: 1 June 2021

\begin{abstract}
The republishing activities of Kaba books carried out by the publisher Kristal Multimedia cannot be separated from the publisher Pustaka Indonesia, one of the earliest publishers managed by local communities in Bukittinggi during the Dutch colonial administration. Sixteen of the eighteen Kaba books that were printed were republished from the publisher Pustaka Indonesia. This research uses the republishing of Kaba books by Kristal Multimedia publisher as its material object. The formal object is doxa which the publisher of Kristal Multimedia expresses. The purpose of this study is to determine the background that causes the publishers of Kristal Multimedia to continue operating and is serious about republishing Kaba books. The research method used is qualitative research methods with interview data collection techniques and the use of documents. The theory used in this research is the arena of cultural production proposed by Pierre Bourdieu, focus the discussion of doxa, heterodoxa and orthodoxa. Doxa expressed by Kristal Multimedia publisher is heterodoxa, contradicting the doksa expressed by the publisher Pustaka Indonesia as a publisher that also produces school and religious textbooks. Kristal Multimedia Publisher focuses on all its publications in Minangkabau cultural books, such as the Kaba book.
\end{abstract}

Keywords: doxa, Kristal Multimedia Publisher, kaba book

\begin{abstract}
Abstrak: Kegiatan penerbitan ulang terhadap buku-buku kaba yang dilakukan oleh penerbit Kristal Multimedia tidak terlepas dari pengaruh penerbit Pustaka Indonesia, yaitu salah satu penerbit awal yang dikelola oleh pribumi di Bukittinggi pada zaman pemerintahan kolonial Belanda. Enam belas dari delapan belas buku kaba yang dicetak merupakan hasil terbitan ulang dari penerbit Pustaka Indonesia. Penelitian ini menjadikan penerbitan ulang buku-buku kaba yang dilakukan oleh penerbit Kristal Multimedia sebagai objek materialnya. Untuk objek formalnya adalah doksa yang diekspresikan oleh penerbit Kristal Multimedia itu. Tujuan dari penelitian ini untuk mengetahui latar belakang yang menyebabkan penerbit Kristal Multimedia mampu bertahan dan memiliki keseriusan dalam menerbitkan ulang buku-buku kaba. Metode penelitian yang digunakan adalah metode penelitian kualitatif dengan teknik pengumpulan data wawancara dan penggunaan dokumen. Teori yang digunakan dalam penelitian ini adalah arena produksi kultural yang dikemukakan oleh Pierre Bourdieu, yaitu pembahasan mengenai doksa, heterodoksa, dan ortodoksa. Doksa yang diekspresikan oleh penerbit Kristal Multimedia adalah heterodoksa, yaitu mempertentangkan doksa yang diekspresikan oleh penerbit Pustaka Indonesia sebagai penerbit yang juga menghasilkan buku-buku teks pelajaran sekolah dan agama. Penerbit Kristal Multimedia memfokuskan semua hasil terbitannya berupa buku-buku kebudayaan Minangkabau, salah satunya buku kaba.
\end{abstract}

Kata kunci: doksa, penerbit Kristal Multimedia, buku kaba

To cite this article:

Herbowo, N. A. S., Anwar, K., \& Ferdinal. (2021). Doksa Penerbit Kristal Multimedia dalam Menerbitkan Ulang Buku-Buku Kaba. Diglosia: Jurnal Kajian Bahasa, Sastra, dan Pengajarannya, 4(2), 149-162. https://doi.org/10.30872/diglosia.v4i2.179 


\section{A. PENDAHULUAN}

Sumatra Barat merupakan daerah yang memiliki tradisi lisan yang kuat, termasuk dalam hal sastranya. Salah satu jenis sastra lisan Minangkabau yang sudah dijadikan dalam bentuk buku adalah kaba. Kaba merupakan cerita berirama, berbentuk narasi (kisahan) dan tergolong cerita panjang (Djamaris, 2002, pp. 77-78). Namun begitu, buku kaba belum berhasil menjangkau khalayak pembaca luas karena berbagai alasan, termasuk penerbit yang mau menggeluti penerbitan genre tersebut. Menerbitkan buku sastra klasik dengan menggunakan bahasa daerah bukan suatu bisnis yang menguntungkan dibanding menerbitkan buku sastra modern atau populer menggunakan bahasa Indonesia. Hal itu disebabkan terbatasnya pembaca yang dapat memahami bahasa yang digunakan.

Selain itu, menerbitkan buku sastra rakyat menggunakan bahasa daerah memiliki risiko mengalami kerugian dikarenakan buku tersebut bukan produk populer. Tidak dapat dipungkiri, sebagai perusahaan yang bergerak dalam bisnis percetakan dan penjualan buku, penerbit tentu juga memiliki orientasi terhadap keuntungan dari produksinya. Oleh sebab itu, sedikit penerbit yang memiliki keinginan untuk menerbitkan buku sastra klasik berbahasa daerah.

Saat ini di Sumatra Barat hanya dijumpai beberapa penerbit yang mau bergerak dalam menerbitkan buku sastra berbahasa daerah, salah satunya adalah penerbit Kristal Multimedia. Di balik kendala dan sulitnya memasarkan buku-buku bergenre sastra rakyat dengan penggunaan bahasa daerah, penerbit ini justru memfokuskan hasil produksinya terhadap hal itu. Sejak awal berdirinya, penerbit ini sudah memiliki tujuan sebagai lembaga yang menyediakan bahan bacaan bertemakan kebudayaan Minangkabau. Semua produk terbitannya berupa buku tambo, pasambahan, seri cerita rakyat Minangkabau, sejarah nagari (daerah di Sumatra Barat), dan kaba. Buku kaba merupakan jenis buku yang paling banyak diproduksi oleh penerbit ini, yaitu delapan belas seri dari tiga puluh dua buku yang sudah diterbitkan. Seri buku kaba yang paling banyak diterbitkan menggunakan bahasa Minangkabau.

Mempertahankan usaha yang bergerak dalam industri penerbitan buku bukan hal mudah, apalagi jika hasil terbitannya itu bukan kategori produk yang populer. Dibutuhkan visi dan keseriusan memanajemen perusahaan tersebut oleh orangorang yang bergerak di dalamnya. Hal itu dilakukan oleh pengelola penerbit Kristal Multimedia dalam mempertahankan hasil produksinya. Salah satu faktor yang mempengaruhi keseriusan itu adalah latar belakang dan pengalaman dari pendiri perusahaan tersebut, yaitu Arfizal Indramaharaja.

Keinginan kuat penerbit Kristal Multimedia dalam menerbitkan ulang bukubuku kaba menjadi hal menarik untuk diamati. Keberadaan penerbit tersebut memiliki peran penting dalam melestarikan sastra Minangkabau. Sastra rakyat yang dihadirkan dengan tradisi lisan menjadi pertimbangan pentingnya mencetak karyakarya itu menjadi bentuk buku. Dalam penelitian ini, pembahasan difokuskan terhadap proses menerbitkan kembali buku-buku kaba tersebut. Hal itu disebabkan oleh beberapa faktor, pertama buku kaba merupakan seri terbanyak yang diterbitkan oleh Kristal Multimedia. Kedua, aspek penjualan buku ini bukan yang paling menguntungkan dari semua buku terbitan Kristal Multimedia. Ketiga, dari semua seri buku yang diterbitkan, seri buku kaba yang hanya dicetak dalam versi digital (ebook). 
Penerbit Kristal Multimedia merupakan penerbit yang memiliki ideologi kuat dalam menentukan tema hasil cetakannya, yaitu buku-buku kebudayaan alam Minangkabau. Melalui ideologi yang diusung penerbit ini mencoba mencapai posisinya dalam arena sastra Indonesia di Sumatra Barat, sebagai lembaga yang mempunyai legitimasi dalam menerbitkan buku sastra Minangkabau. Penelitian ini menggunakan kajian arena produksi kultural yang dikemukan oleh Bourdieu mengenai konsep doksa. Bourdieu (2016, p. 15) menyatakan bahwa dalam kajian sastra harus mempertimbangkan peran produser makna dan nilai karya, seperti kritikus, penerbit, pengelola galeri dan agen yang bertugas membuat konsumen mampu mengetahui dan mengakui karya sastra tersebut. Dalam hal ini, pengaruh dari penerbit buku sastra merupakan bagian dari studi konteks yang dikemukakan oleh Bourdieu.

Kajian terhadap penerbit Kristal Multimedia sebagai penerbit yang menjaga eksistensi sastra Minangkabau dengan segala bentuk legitimasinya penting untuk dilakukan. Penelitian ini meliputi penelusuran doksa yang digunakan Kristal Multimedia dalam penerbitan buku-buku kaba. Doksa adalah perangkat aturan, nilai, konvensi dan wacana yang mengatur arena secara keseluruhan dan berpengaruh sejak lama atau disajikan sebagai akal sehat (Bourdieu, 1996, p. 228). Dalam menganalisis doksa akan dihadapkan pada heterodoksa dan ortodoksa. Menurut Bourdieu (1995, p. 169) ortodoksa adalah wacana yang mengakui doksa, sedangkan heterodoksa adalah wacana yang mempertentangkan doksa sebelumnya.

Untuk memasukkan doksa tersebut, agen pada penerbit Kristal Multimedia tentu sangat berperan penting dalam melegitimasi setiap keputusan proses penerbitan buku kaba. Agen tersebut berperan terhadap pencapaian posisi penerbit Kristal Multimedia dalam arena sastra Indonesia dan sebagai penerbit yang konsisten beroperasi hingga saat ini. Mengingat bahwa industri penerbitan buku di Sumatra Barat bukanlah sebuah industri ideal dengan perolehan keuntungan yang besar dibanding usaha kuliner.

Kajian doksa dalam penerbitan ulang buku sastra Minangkabau (kaba) yang dilakukan oleh penerbit Kristal Multimedia, secara teoretis bertujuan untuk mengetahui latar belakang yang menyebabkan penerbit itu mampu bertahan dan memiliki keseriusan dalam menghasilkan bahan bacaan kebudayaan Minangkabau, dan habitus agen yang mengelola penerbit tersebut. Secara praktis, penelitian ini diharapkan sebagai bentuk pemetaan dan pendataan penerbitan buku sastra Minangkabau (kaba) dan hasil terbitannya sebagai bentuk pengembangan dari industri kreatif dan implementasi dari revolusi industri 4.0. Sehingga dapat menjadi pertimbangan dalam perumusan kebijakan berkenaan dengan pelestarian nilai budaya berbasis kearifan lokal di Sumatra Barat melalui penerbitan buku sastra lisan (kaba).

Beberapa peneliti yang sudah membahas penerbit Kristal Multimedia adalah Herbowo \& Sulastri (2020), Fadila (2018), Sudarmoko (2016), dan Sunarti (2013). Namun begitu, keempat penelitian tersebut tidak satu pun yang menyinggung pembahasan doksa penerbit Kristal Multimedia dalam menerbitkan ulang buku-buku kaba. Kesamaan objek yang dilakukan dalam penelitian Herbowo \& Sulastri (2020), serta Sudarmoko (2016) tertuju pada pembicaraan mengenai sejarah dan buku hasil terbitan dari penerbit Kristal Multimedia. Herbowo \& Sulastri (2020) dalam penelitiannya menyinggung mengenai profil dari Kristal Multimedia, mulai dari kapan berdirinya, siapa pendirinya, dan di mana penerbit itu berada. Kemudian 
mereka juga mencatat semua buku kaba dan tambo yang sudah diterbitkan oleh penerbit tersebut. Sudarmoko (2016) lebih rinci dalam mengulas penerbit Kristal Multimedia, terutama pembicaraan terhadap manajemen pengelolaannya. Ia membahas persoalan sistem manajemen yang dilakukan Kristal Multimedia dalam menjalankan usahanya itu, dan juga membicarakan mengenai penerbitan buku Kaba Cindua Mato.

Dua penelitian lainnya, yaitu Fadila (2018) dan Sunarti (2013) berkaitan dengan sejarah penerbitan buku di Sumatra Barat, terutama penerbit-penerbit buku yang berada di Kota Bukittinggi sebelum zaman kemerdekaan. Fadila (2018) membicarakan kondisi sosial masyarakat di Kota Bukittinggi pada tahun 19201940-an yang melatarbelakangi munculnya usaha penerbitan buku yang diprakarsai dan dikelola oleh masyarakat pribumi. Sedangkan Sunarti (2013) melakukan penelitiannya dengan cakupan yang lebih luas, yaitu pembicaraan mengenai sejarah penerbitan yang ada di Sumatra Barat yang meliputi penerbitan di Padang, Padangpanjang, Bukittinggi, dan Payakumbuh. Kedua penelitian itu menjadi kajian pustaka dan sumber data karena memuat pembahasan mengenai penerbit Pustaka Indonesia, yaitu usaha penerbitan yang menjadi cikal bakal berdirinya Kristal Multimedia. Sedangkan beberapa penelitian yang menggunakan analisis arena produksi kultural Bourdieu terhadap lembaga sastra terutama membahas doksa dalam kajian sastra, antara lain berupa kajian terhadap arena produksi kultural komunitas Sastra Pelangi Malang (Nilofar, 2020), kajian arena produksi kultural kasus penerbit Bandar Publishing di Kota Banda Aceh (Linda, 2019), doksa, kekerasan simbolik dan habitus dari lembaga Dewan Kesenian Jakarta (Zurmailis \& Faruk, 2017), strategi dan legitimasi komunitas sastra di Yogyakarta (Salam \& Anwar, 2015), dan bengkel sastra Balai Bahasa DIY (Zamzuri, 2015).

\section{B. METODE}

Penelitian ini merupakan penelitian kualitatif dengan objek material penerbit Kristal Multimedia dalam menerbitkan ulang kaba, dan objek formal doksa yang diterapkan oleh penerbit tersebut dalam proses penerbitan ulang buku-buku kaba. Penelitian menggunakan teori arena produksi kultural Bourdieu, yaitu pembahasan mengenai doksa dari lembaga sastra. Dalam pandangan Bourdieu (2016, p. 15) kajian sastra mestinya tidak hanya menjadikan produksi material sebagai objek kajiannya, tapi juga produksi simbol karya, yaitu produksi keyakinan terhadap nilai karya tersebut. Sumber data utama penelitian ini diperoleh dengan cara wawancara dan penggunaan dokumen. Jenis wawancara yang dilakukan adalah wawancara baku terbuka, yaitu wawancara yang menggunakan seperangkat pertanyaan baku (Moleong, 2014, p. 188). Kegiatan wawancara menggunakan daftar pertanyaan yang sudah disiapkan sebelumnya dan media perekam suara. Narasumber dalam penelitian ini adalah pendiri sekaligus pemimpin dari penerbit Kristal Multimedia, yaitu Arfizal Indramaharaja.

Penggunaan dokumen perlu dilakukan dalam penelitian ini karena berguna sebagai bukti untuk suatu pengujian dan sebagai sumber data yang autentik. Dokumen yang digunakan dalam penelitian ini terbagi menjadi dua, yaitu dokumen pribadi dan resmi. Dokumen pribadi adalah catatan atau karangan seseorang secara tertulis tentang tindakan, pengalaman, dan kepercayaannya (Moleong, 2014, p. 217). Dokumen pribadi yang digunakan dalam penelitian ini adalah catatan dari pendiri 
atau pimpinan penerbit Kristal Multimedia. Sedangkan dokumen resmi berupa Surat Izin Usaha atau akta pendirian penerbit.

Analisis data dalam penulisan penelitian ini dibagi dalam dua tahapan, tahap pertama menjelaskan perjalanan penerbitan ulang buku-buku kaba yang dilakukan oleh penerbit Kristal Multimedia dan keterkaitannya dengan Pustaka Indonesia dan Balai Buku Indonesia. Hal itu dilakukan dalam menentukan habitus yang dimiliki oleh agen Kristal Multimedia. Tahap kedua melakukan analisis terhadap doksa yang diterapkan oleh penerbit Kristal Multimedia.

\section{PEMBAHASAN}

\section{Perjalanan Penerbitan Ulang Buku-buku Kaba oleh Penerbit Kristal Multimedia}

Penerbit Pustaka Indonesia merupakan salah satu usaha penerbitan swasta di Bukittinggi yang dikelola oleh pribumi pada zaman pemerintahan kolonial Belanda. Umumnya usaha penerbitan swasta awal di Sumatra Barat pada masa itu memang lebih memfokuskan hasil produksi mereka terhadap buku-buku kebudayaan lokal yang ingin disuarakan oleh para pemiliknya. Seperti yang diungkapkan Sunarti (2013, p. 55) ketertarikan pribumi dalam memasuki dunia usaha percetakan dan penerbitan lebih didasarkan pada keinginan untuk menyuarakan kepentingan kelompok dan organisasi yang menjadi penaung atau pemodal usaha tersebut.

Pada masa pemerintahan kolonial Belanda, Kota Bukittinggi merupakan daerah yang banyak menghasilkan penerbit yang dikelola oleh pribumi di Sumatra Barat. Suryadi (dalam Azwar, 2003, p. 610) menyatakan bahwa pada rentang tahun 19201940-an di Fort de Kock (sekarang bernama Bukittinggi) bermunculan banyak penerbit dan usaha percetakan yang menerbitkan buku-buku dalam bahasa Melayu dan Minangkabau. Berbeda dari masa sebelumnya (abad ke-19), penerbit-penerbit yang muncul itu lebih menumpukan perhatian untuk menerbitkan buku-buku daripada surat kabar. Buku-buku yang diterbitkan itu umumnya mengenai adat dan sastra tradisional Minangkabau, serta berbagai aspek tentang agama Islam. Hal itu sesuai dengan tujuan awal para pemilik usaha penerbitan tersebut, yaitu sebagai sarana dalam penyampaian informasi daerah mereka. Dengan menggunakan bahasa Melayu dan Minangkabau lebih memudahkan para pembacanya untuk memahami hasil terbitan mereka.

Selain itu, upaya menerbitkan buku kebudayaan Minangkabau terutama buku kaba, juga sebagai bahan media pembelajaran bagi masyarakat Sumatra Barat. Sebagaimana yang dinyatakan Karim dan Pramono (2016, p. 590), bahwa kepentingan semula dicetaknya buku kaba adalah untuk penelitian bahasa. Akan tetapi, penerbitan itu memberikan keuntungan terhadap berbagai sektor. Tidak sekadar memberikan kontribusi terhadap perkembangan dunia sastra, namun juga berdampak bagi keuntungan bisnis yang diperoleh oleh penerbitnya. Hal itu terlihat dari maraknya penerbit yang ikut terhadap usaha tersebut hingga tahun 1950-an. Setidaknya ada beberapa penerbit yang berada di Bukittinggi dan Payakumbuh memiliki konsekrasi terhadap penerbitan kaba. Seperti yang disampaikan Djamaris (2002, pp. 8-9), beberapa penerbit yang menerbitkan buku kaba pada tahun 1950-an sampai 1960-an yang terdapat di Bukittinggi, yaitu penerbit Tsamaratul Ichwan, CV. Indah, Arga, dan Pustaka Indonesia, sedangkan di Payakumbuh penerbit Eleonora dan Limbago. 
Maraknya penerbitan buku-buku kaba yang dilakukan oleh penerbit-penerbit di Sumatra Barat terjadi pada zaman orde baru. Hal itu dikarenakan dukungan pemerintah pada saat itu yang menginginkan adanya penerbitan buku-buku sastra klasik berbahasa daerah di Indonesia, termasuk sastra Minangkabau seperti kaba. Menurut Pramono (2008, pp. 6-7) sejak tahun 1978 penerbitan kaba banyak dilakukan. Hal itu ditunjang dengan adanya bantuan dana dari proyek penerbitan buku sastra Indonesia dan daerah oleh Departemen Pendidikan dan Kebudayaan. Namun tidak berlaku bagi Pustaka Indonesia maupun Balai Buku Indonesia. Kedua penerbit tersebut memang memiliki keseriusan dalam menghadirkan bahan bacaan kebudayaan Minangkabau, terutama sastra tanpa mengharapkan bantuan dari pihak lain, termasuk pemerintah melalui Depdikbud.

Perjalanan Pustaka Indonesia dalam dunia penerbitan tidak selalu dihadapkan dengan kondisi yang menguntungkan. Berbagai kendala dan persoalan dialami, seperti persaingan bisnis yang semakin kuat dan lemahnya pengelolaan usaha yang dilakukan oleh pemiliknya. Banyak penerbit-penerbit lokal di Bukittinggi dan Payakumbuh yang punya kecenderungan terhadap penerbitan kaba berhenti beroperasi. Hasanuddin WS (dalam Azwar, 2003, p. 299) mengungkapkan satu faktor penyebab industri penerbitan di Minangkabau sulit untuk tumbuh, bahkan cenderung mundur diakibatkan pengelolaannya yang tidak pernah bergeser pola manajemen keluarga. Setidaknya hal ini menjadi indikasi bahwa pada saat itu penerbit-penerbit buku kaba tersebut belum menerapkan sistem manajemen yang profesional dalam pengelolaan usaha penerbitannya.

Pustaka Indonesia menjadi salah satu penerbit swasta awal yang sudah berhenti beroperasi pada saat ini. Sebelum menghentikan usaha penerbitannya, Pustaka Indonesia sempat melebarkan jenis usahanya terhadap penjualan barang cetakan. Keberadaan penerbit Pustaka Indonesia secara fisik memang sudah tidak ditemukan. Namun, tekad perusahaan itu dalam menyediakan bahan bacaan bertemakan kebudayaan Minangkabau masih tetap berlanjut. Pada tahun 1982, berawal dari keinginan kuat Arfizal Indramaharaja untuk terus melanjutkan usaha orang tuanya dalam industri percetakan dan penerbitan, ia mendirikan perusahaan baru dengan nama Balai Buku Indonesia pada 15 Juli 1982. Hanya saja, perusahaan itu mengawali produksi usahanya bukan terhadap penerbitan buku melainkan pengadaan barang cetakan.

Balai Buku Indonesia tergolong sukses dalam penyediaan barang cetakan di Sumatra Barat. Hal itu dibuktikan dengan kawasan pemasaran yang tidak hanya sebatas Kota Bukittinggi saja, melainkan juga menjangkau daerah Payakumbuh, Padangpanjang, dan Padang. Tentu saja hal itu menjadi catatan prestasi bagi perusahaan. Dengan pertimbangan sudah mulai meluasnya jangkauan pemasaran, muncul keinginan oleh Arfizal untuk mulai memasuki usaha penerbitan buku. Tiga tahun setelah pengesahan akta pendirian, pada tahun 1985 Balai Buku Indonesia mulai menerbitkan buku-buku kaba. Usaha penerbitan buku kaba yang dilakukan perusahaan itu adalah menerbitkan kembali beberapa buku-buku kaba yang sudah pernah diterbitkan oleh Pustaka Indonesia, yaitu buku Kaba Umbuik Mudo, Kaba Cindua Mato dan Kaba Anggun Nan Tongga.

Balai Buku Indonesia sempat mengalami masa krisis yang berujung terhadap berhenti beroperasinya penerbit tersebut. Tidak hanya berhenti dalam usaha penerbitan buku saja, namun juga terhadap pengadaan barang cetakan yang menjadi penghasil keuntungan besar bagi perusahaan ini. Banyak faktor yang menyebabkan 
Balai Buku Indonesia berhenti berproduksi, salah satunya adalah kesibukan lain dari masing-masing pekerjanya. Pada tahun dua ribu, Afrizal Idramaharaja berkeinginan kembali untuk mengaktifkan industri penerbitan bukunya. Berbagai macam hal yang mendorongnya untuk kembali aktif pada dunia usaha tersebut, salah satunya adalah minimnya bahan bacaan kebudayaan Minangkabau pada saat itu. Sejauh pengamatannya, Arfizal Indramaharaja melihat buku-buku bertemakan kebudayaan Minangkabau, terutama sastra Minangkabau (tambo, pasambahan, dan kaba) sangat minim tersedia di beberapa toko buku besar yang ada di kota Bukittinggi dan Padang.

Wujud dari kegelisahan itu, Arfizal membentuk sebuah penerbit yang memiliki kekhususan terhadap buku-buku bertemakan kebudayaan Minangkabau di Sumatra Barat. Penerbit yang ia didirikan itu bernama Kristal Multimedia. Dengan nama itu, Afrizal Indramaharaja berharap akan terjadi perubahan besar dari usaha industri penerbitan yang ia jalankan tersebut. Dengan mengambil langkah untuk fokus terhadap bahan bacaan kebudayaan Minangkabau, Kristal Multimedia kembali memainkan peran Pustaka Indonesia dan Balai Buku Indonesia dalam dunia penerbitan di Sumatra Barat.

Penerbitan buku kaba di bawah label Kristal Multimedia mulai dilakukan pada tahun dua ribu tiga, tiga tahun setelah didaftarkannya perusahaan tersebut. Bukubuku kaba yang diterbitkan ulang tidak hanya naskah yang diperoleh dari Pustaka Indonesia saja, namun juga dari penerbit Pustaka Arga dan Tsamaratul Ikhwan yang berada di Bukittinggi. Sedangkan buku yang naskahnya perdana diterbitkan oleh penerbit Kristal Multimedia adalah buku Tambo Minangkabau dan dua buku tentang sejarah Nagari Kurai.

Untuk sebuah penerbit lokal yang menerbitkan buku sastra dengan menggunakan bahasa daerah, Kristal Multimedia merupakan penerbit yang produktif. Khusus buku kaba sudah menerbitkan lebih dari empat kali, yaitu tahun 2003, 2004, 2005, 2014, dan 2018. Selain itu, penerbit tersebut juga masih mampu bertahan hingga saat ini. Beberapa penerbit lokal yang juga memiliki kesamaan terhadap hasil terbitannya sudah mulai berhenti beroperasi seperti Eleonoro dan Limbago, atau mengubah fokus penerbitan mereka seperti penerbit Merapi yang hanya bergerak dalam bidang percetakan saja.

Keberhasilan penerbit Kristal Multimedia yang masih mampu bertahan hingga era revolusi industri 4.0 tidak terlepas dari pengelolaan manajemen perusahaan yang sudah profesional. Sewaktu masih mengelola Balai Buku Indonesia, Arfizal lebih dominan dalam mengerjakan usaha penggandaan barang cetakan dan penerbitan buku dari perusahaan tersebut. Sedangkan ketika di Kristal Multimedia, Arfizal sudah mulai menata dengan profesional setiap bidang dan sumber daya manusia yang ada di dalamnya. Perusahaan ini sudah menerapkan setiap bidang dikerjakan oleh orang memiliki kompetensi terhadap bidang itu. Adapun bidang-bidang dari manajemen perusahaan itu adalah pemimpin perusahaan, bidang produksi, bidang keuangan, bidang penjualan (marketing).

Kebijakan perusahaan dalam menentukan jumlah eksemplar buku yang dicetak menjadi poin utama dalam keberhasilan penerbit ini untuk mampu bertahan hingga saat ini. Banyak penerbit lokal yang terkendala beroperasi diakibat oleh biaya produksi yang cukup tinggi. Hal itu disebabkan oleh penentuan jumlah eksemplar yang ditetapkan dalam setiap cetaknya. Seperti yang diungkapkan oleh Putra dan Antara (2019, p. 488) mengenai penerbitan buku Sastra Bali Modern yang membutuhkan biaya hingga lima juta rupiah untuk seratus hingga dua ratus 
eksemplar. Belum lagi faktor penjualan buku tersebut, bahwa buku-buku sastra berbahasa daerah bukan jenis produk dengan penjualan yang bagus dibanding bukubuku sastra berbahasa Indonesia.

Penerbit Kristal Multimedia mempunyai cara produksi tersendiri dalam menyiasati permasalahan biaya produksi yang cukup tinggi. Cara yang dilakukan adalah melakukan cetak ulang dengan jumlah yang diminta oleh si pemesan atau toko buku yang bekerja sama dengan penerbit. Pada terbitan awal tahun dua ribu tiga, buku-buku kaba dicetak sebanyak lima ratus eksemplar, untuk cetakan selanjutnya disesuaikan dengan permintaan si pemesan, yaitu toko buku yang bekerja sama dengan Kristal Multimedia. Kepiawaian para karyawan Kristal Multimedia dalam memanfaatkan perkembangan teknologi dan informasi juga berdampak meluasnya jenis produksi dari penerbit ini. Tidak hanya bergerak dalam sektor penerbitan dengan menggunakan kertas saja, namun juga menyediakan buku dengan format digital (ebook). Khusus untuk buku digital hanya diberlakukan terhadap buku-buku kaba saja karena kaba merupakan buku dengan seri terbanyak, yaitu delapan belas seri dengan jumlah halaman yang tidak terlalu banyak (berkisar delapan puluh hingga seratus tiga puluh halaman) sehingga untuk membacanya dengan menggunakan smartphone akan lebih mudah. Penjualan buku kaba versi digital mulai dilakukan pada bulan Maret 2020.

Pemanfaatan teknologi informasi juga digunakan dalam mempromosikan bukubuku yang diterbitkan. Sampai saat ini penerbit Kristal Multimedia menggunakan media sosial seperti facebook dengan nama akun "Kristal Multimedia" dan instagram "Redaksi Kristal Multimedia". Tidak hanya itu, penerbit ini juga mempunyai laman situs internet tidak berbayar, yaitu www.kristalmultimedia.blogspot.com yang memuat informasi ringkasan dari semua buku yang sudah diterbitkan oleh penerbit tersebut. Melalui media sosial dan laman blogspot itu buku-buku Kristal Multimedia banyak diketahui oleh masyarakat. Bahkan ada pembeli dari negara Malaysia yang merupakan perantau asal Minangkabau melakukan pemesanan berdasarkan informasi yang ia ketahui dari laman media sosial penerbit tersebut.

Sampai saat ini, penerbit Kristal Multimedia sudah menerbitkan tiga puluh dua judul buku, dan delapan belas di antaranya adalah buku kaba. Kemampuan penerbit ini untuk terus beroperasi dalam memproduksi buku-buku kebudayaan Minangkabau tidak terlepas dari modal dan strategi yang dilakukan oleh agennya. Oleh sebab itu, pembahasan mengenai sejarah penerbitan buku kaba oleh penerbit Kristal Multimedia ini perlu untuk dilakukan, bahwa pengaruh dua penerbit sebelumnya dan keterlibatan Arfizal di dalamnya berdampak terhadap pengelolaan Kristal Multimedia sampai sekarang.

\section{Doksa Kristal Multimedia dalam Menerbitkan Ulang Buku-Buku Kaba}

Perubahan haluan jenis buku yang diterbitkan dan fokus usaha yang dikerjakan antara penerbit Pustaka Indonesia dan Balai Buku Indonesia dengan penerbit Kristal Multimedia dapat dilihat melalui konsep doksa. Dalam mengidentifikasi doksa dari penerbit ini dapat dilihat dari latar belakang pendirinya yang pernah terlibat dalam pengelolaan Pustaka Indonesia dan Balai Buku Indonesia. Namun begitu, Kritsal Multimedia memiliki perbedaan terhadap orientasi usaha dibandingkan dua penerbitan sebelumnya, yaitu tidak lagi bergerak dalam pengadaan barang dan jasa. Selain itu, penerbit ini tidak menerbitkan buku-buku yang tidak bertemakan kebudayaan Minangkabau. 
Pustaka Indonesia dan Balai Buku Indonesia memiliki pandangan yang berbeda dengan Kristal Multimedia. Perbedaan mendasar terlihat dari semua buku terbitan Kristal Multimedia dan jenis usaha yang dilakukan. Pustaka Indonesia tidak hanya menerbitkan buku bertemakan kebudayaan Minangkabau, walaupun hasil terbitan ini yang paling dominan, tapi perusahaan itu juga pernah menerbitkan buku-buku yang bukan bertemakan kebudayaan Minangkabau. Sedangkan Balai Buku Indonesia lebih fokus bergerak terhadap pengadaan barang cetakan, walaupun juga menerbitkan beberapa buku terbitan ulang dari Pustaka Indonesia.

Penerbit Pustaka Indonesia merupakan salah satu penerbit yang memiliki kecenderungan hasil terbitannya berupa buku-buku kebudayaan Minangkabau, terutama sastra Minangkabau seperti buku tambo, pasambahan, dan kaba. Namun begitu, Pustaka Indonesia tidak hanya sekadar usaha penerbitan saja, ia juga sebagai usaha percetakan dan penggandaan barang cetakan. Jenis usaha penggandaan itulah yang diadopsi seutuhnya oleh Balai Buku Indonesia (nama awal perusahaan sebelum menjadi Kristal Multimedia).

Berbeda dengan dua penerbit sebelumnya, penerbit Kristal Multimedia memiliki ideologi yang kuat terhadap hasil terbitan dan jenis usaha yang dijalankan. Jika penerbit sebelumnya, Pustaka Indonesia dan Balai Buku Indonesia masih menerima menerbitkan beberapa buku di luar kebudayaan Minangkabau, seperti buku-buku teks pelajaran bagi sekolah dasar dan menengah, sedangkan penerbit Kristal Multimedia tidak lagi menerbitkan naskah-naskah yang tidak mengandung tema kebudayaan Minangkabau. Semua buku yang diterbitkan haruslah bertemakan kebudayaan Minangkabau, baik itu sastra Minangkabau, cerita rakyat Minangkabau, maupun sejarah pembentukan daerah di Sumatra Barat.

Penerbit Pustaka Indonesia pada saat masih aktif beroperasi hanya memiliki kecenderungan saja terhadap penerbitan bahan bacaan kebudayaan Minangkabau. Kecenderungan yang dimaksud adalah hasil terbitan dari penerbit itu lebih banyak buku-buku kebudayaan Minangkabau, bukan berati tidak pernah menerbitkan buku selain itu. Beberapa buku di luar terbitan kebudayaan Minangkabau adalah bukubuku teks pelajaran untuk siswa sekolah dasar dan buku-buku ajaran agama islam. Dalam menentukan jenis usaha, penerbit Kristal Multimedia juga memiliki perbedaan dari dua penerbit sebelumnya, yaitu tidak lagi menjadi perusahaan yang juga bergerak dalam pengadaan barang cetakan. Balai Buku Indonesia sebenarnya merupakan perusahaan yang bergerak dalam usaha penjualan barang cetakan seperti kertas dan peralatan kantor lainnya. Hal itu tentu saja menuntut perusahaan ini harus membangun relasi yang banyak agar barang yang mereka perdagangkan laku terjual, salah satunya bekerja sama dengan pihak pemerintah. Dalam hal penerbitan buku, dapat dikatakan bahwa Balai Buku Indonesia menjadikannya sebagai usaha sampingan.

Walaupun masih dipimpin oleh orang yang sama pada saat di Balai Buku Indonesia yaitu Arfizal Indramaharaja, penerbit Kristal Multimedia sudah melakukan perombakan secara menyeluruh terhadap fokus bisnisnya itu. Bahkan penerbit itu juga mempunyai sikap yang tegas terhadap hasil produksinya, yaitu tidak menerbitkan buku-buku yang bukan bertemakan kebudayaan Minangkabau. Hal itu berbeda dari dua penerbit pendahulunya yang menyediakan produk tersebut. Inilah yang menjadi dasar pembeda atau pertentangan yang dilakukan oleh Kristal Multimedia terhadap dua penerbit sebelumnya. Bahkan dengan agen yang ada sejak zaman Pustaka Indonesia masih beraktivitas sampai di masa Kristal Multimedia. 
Melakukan analisis dan pembahasan terhadap doksa terdapat dua istilah yang berkaitan yaitu heterodoksa dan ortodoksa. Bahwa dalam perjalanannya terdapat beragam pendapat, ada yang mempertahankannya namun ada pula yang membantah atau menggugatnya. Pada pembahasan doksa penentangan atau doksa yang berbeda itu dinamakan heterodoksa. Doksa yang diusung oleh Kristal Multimedia dapat digolongkan sebagai heterodoksa dikarenakan tidak lagi meneruskan sepenuhnya jenis usaha yang sudah dilakukan oleh dua penerbit pendahulunya, walaupun agen yang mendirikan Kristal Multimedia juga terlibat dalam kegiatan dua penerbit sebelumnya.

Komitmen Kristal Multimedia dalam menyediakan bahan bacaan dengan tema kebudayaan Minangkabau tidak dapat dipisahkan dari kegiatan produksi yang sudah dilakukan terlebih dahulu oleh Pustaka Indonesia dan Balai Buku Indonesia. Dalam perspektif Bourdieu (2011, p. 83) keterkaitan itu mengacu kepada konsep habitus, yaitu sebuah kebiasaan yang dibentuk oleh pengalaman dan pembelajaran dari agen secara eksplisit. Keterlibatan Arfizal Indramaharaja sejak bangku sekolah menengah pertama dalam usaha penerbitan buku memberikan ia banyak pembelajaran yang kemudian mendorongnya untuk kembali menjalankan usaha tersebut. Pengalaman dalam mengelola usaha dan ilmu yang diberikan oleh sosok sang ayah membangun struktur berpikir Arfizal sebagai habitus yang membawanya mempunyai konsep dalam menentukan arah perjalanan Kristal Multimedia.

Melalui penerbit Kristal Multimedia, Arfizal menyempitkan sasaran produksi yang telah dikerjakan bersama dua penerbit sebelumnya. Hal itu dilakukan demi memperkuat identitas dan mempermudah proses produksi dari perusahaan tersebut. Berbeda dari dua penerbit sebelumnya yang juga bergerak terhadap pengadaan barang cetakan yang memungkinnya untuk memiliki relasi yang luas, baik kepada sesama pihak swasta maupun terhadap pemerintahan. Melihat luasnya cakupan bisnis dan tidak terbatasnya jenis buku yang diterbitkan, Pustaka Indonesia pada saat itu dapat dikatakan sebagai salah satu usaha penerbitan besar di Sumatra Barat. Dengan tidak lagi mengikuti bisnis yang sudah dilakukan itu, setidaknya Kristal Multimedia telah kehilangan beberapa koneksi, terutama dalam hal pembeli atau pelanggan barang cetakan.

Penerbit Kristal Multimedia tidak lagi melanjutkan kegiatan penerbitan bukubuku teks pelajaran sekolah dasar dan menengah. Hal itu berbeda dengan penerbit sebelumnya, yaitu Pustaka Indonesia dan Balai Buku Indonesia, meskipun kedua penerbit tersebut terkait satu sama lain. Selain itu, Kristal Multimedia juga tidak lagi melibatkan diri terhadap usaha pengadaan barang cetakan. Perusahaan tersebut memfokuskan jenis usahanya terhadap penerbitan buku-buku kebudayaan Minangkabau saja. Perubahan orientasi bisnis ini dalam analisis doksa dapat dimaknai sebagai heterodoksa.

Heterodoksa tersebut dapat dilihat berdasarkan visi dari penerbit Kristal Multimedia yaitu "Menjadi Penerbit Terkemuka dan Profesional yang Berfokus pada Buku-Buku Kebudayaan Minangkabau". Pada pengonsepan visi dapat dipahami bahwa penerbit ini sudah mempunyai ideologi yang kuat terhadap penerbitan buku-buku kebudayaan Minangkabau. Habitus pada penerbit Pustaka Indonesia dan Balai Buku Indonesia yaitu menerbitkan buku-buku teks pelajaran sekolah dan buku keagamaan tidak lagi dikerjakan oleh Kristal Multimedia. Hal itu bukan berarti bahwa penerbit ini tidak pernah menerima naskah yang tidak bertemakan kebudayaan Minangkabau. 
Heterodoksa terhadap doksa Pustaka Indonesia dan Balai Buku Indonesia juga terjelaskan dengan misi yang dikerjakan oleh agen Kristal Multimedia. Ketegasan pihak Kristal Multimedia dalam hal menerbitkan buku-buku bertemakan kebudayaan Minangkabau diungkapkan langsung oleh pendiri sekaligus pemimpin penerbit itu, Afrizal Indramaharaja. Kristal Multimedia pernah menolak beberapa naskah yang tidak memuat kebudayaan Minangkabau atau memberikan beberapa komentar dan saran bagi naskah yang dianggap dapat memuat tema budaya Minangkabau. Sikap penerbit yang memberikan catatan kepada para penulis tersebut bukan sebuah penilaian dari redaksi bahwa naskah yang bersangkutan tidak bagus. Sikap tersebut diambil oleh pihak penerbit dalam rangka menjalankan visi mereka sebagai penerbit kebudayaan Minangkabau yang profesional. Selain itu, sikap tersebut juga sebagai bentuk dari bagaimana penerbit Kristal Multimedia menjalankan doksa yang dimiliki sehingga pada akhirnya dapat menjadi doksa dominan yang selalu dipertahankan oleh agennya. Selain itu, tujuan utama mendirikan Kristal Multimedia adalah untuk melestarikan kebudayaan Minangkabau yang kebanyakan menggunakan tradisi lisan. Dengan dijadikan dalam bentuk cetak, hal itu dapat membantu generasi selanjutnya untuk dapat mengetahui kebudayaan Minangkabau terutama sastra Minangkabau seperti kaba. Kemudian juga untuk memenuhi kebutuhan masyarakat terhadap bahan bacaan tentang budaya Minangkabau.

Penerbit Kristal Multimedia memiliki doksa dalam penerbitan buku-buku sastra Minangkabau. Doksa yang diusung tersebut turut menegaskan posisi penerbit dalam arena sastra Indonesia di Sumatra Barat. Penerbit Kristal Multimedia menempati prinsip hierarki otonom yang lebih mengedepankan prestise kesusastraan. Hal itu terkait dengan ketegasan untuk menerbitkan buku-buku bertemakan kebudayaan Minangkabau. Di sisi lain, doksa tersebut juga tampak pada ruang produksi penerbit Kristal Multimedia yang cenderung pada produksi terbatas. Terkait dengan sejarahnya, penerbit yang semula memiliki produksi terhadap proyek yang lebih besar, sebagaimana saat masih bernama Pustaka Indonesia, berputar haluan ke proyek atau ruang yang lebih kecil untuk hanya menerbitkan buku-buku terkait kebudayaan Minangkabau.

\section{PENUTUP}

Penerbit Kristal Multimedia merupakan penerbit yang konsisten dengan hasil produksinya, yaitu menerbitkan buku-buku kebudayaan Minangkabau salah satunya adalah buku kaba. Enam belas dari buku kaba tersebut merupakan cetakan ulang dari penerbit Pustaka Indonesia. Keterkaitan antara pendiri Pustaka Indonesia dengan pendiri Kristal Multimedia menjadi faktor utama dalam hal proses penerbitan ulang sehingga dalam hal penerbitan buku-buku kaba penerbit Kristal Multimedia hanya meneruskan kerja sama yang telah disepakati antara Pustaka Indonesia dengan semua penulis buku kaba tersebut. Keterkaitan dan pengalaman itu yang menjadi habitus bagi agen Kristal Multimedia sehingga membentuk struktur berpikirnya dalam menjalankan usaha tersebut.

Berdasarkan uraian tersebut maka dapat dikatakan bahwa penerbit Kristal Multimedia memiliki doksa tertentu, atau perangkat aturan dan nilai tertentu yang diekspresikan dalam menerbitkan buku-buku kaba. Doksa tersebut ialah sebagaimana yang terkait dengan semboyannya, yaitu Penerbit Buku Alam Minangkabau. Adanya doksa yang diusung oleh agen berserta modal simbolik yang 
dimiliki turut mempertegas posisi penerbit tersebut. Selain itu, doksa tersebut kemudian terkait dengan karya-karya yang diproduksi dalam arena sastra, yaitu berupa karya dalam produksi terbatas, atau dengan kata lain tidak mengikuti kehendak atau selera pasar secara luas.

\section{DAFTAR PUSTAKA}

Azwar, N. (Ed.). (2003). Menyulam Visi DKSB dalam Catatan. Padang: Dewan Kesenian Sumatra Barat.

Bourdieu, P. (2011). Choses Dites: Uraian dan Pemikiran. Terjemahan Ninik Rochani Sjams. Bantul: Kreasi Wacana.

Bourdieu, P. (2016). Arena Produksi Kultural: Sebuah Kajian Sosiologi Budaya. Terjemahan Yudi Santosa. Bantul: Kreasi Wacana.

Bourdieu, P. (1996). The Rule of Art, Genesis and Structure of the Literary Field. Trans. By Susan Emanuel. Cambridge: Polity Press.

Bourdieu, P. (1995). Outline of A Theory of Practice. Trans. By Richard Nice. Cambridge:

Djamaris, E. (2002). Pengantar Sastra Rakyat Minangkabau. Jakarta: Yayasan Obor Indonesia.

Fadila, Z. (2018). Penerbitan Minangkabau pada Masa Kolonial: Sejarah Penerbitan Buku di Fort de Kock (Bukittinggi) 1901-1942. Yogyakarta: Gre Publishing.

Herbowo, N. A. S. \& Sulatri. (2020). Reprinting of Kaba and Tambo Books by Kristal Multimedia Publisher. Wanastra, 12(2), 223-228. https://doi.org/10.31294/w.v12i2.8744

Karim, A. R. B. A. dan Pramono. (2016). Khasanah Bahasa, Sastra dan Budaya Serumpun: Kumpulan Tulisan. Padang: Pusat Studi dan Informasi Kebudayaan Minangkabau (PSIKM) Universitas Andalas bekerja sama dengan Fakultas Ilmu Budaya Universitas Andalas.

Linda, L. (2019). Kekuasaan dan Kepentingan Internal Lembaga: Kajian Arena Produksi Kultural Bourdieu (Studi Kasus Penerbit Bandar Publishing di Kota Banda Aceh). Aceh Anthropological Journal, 3(2), 157-177. https://doi.org/10.29103/aaj.v3i2.2779.

Moleong, L. J. (2014). Metodologi Penelitian Kualitatif. Bandung: Remaja Rosdakarya.

Nilofar, N. (2020). Arena Produksi Kultural Komunitas Pelangi Sastra Malang. Alayasastra, 16(1), 119-133. https://doi.org/10.36567/aly.v16i1.498

Putra, I. N. D., \& Antara, I. G. N. (2019). Tantangan dan Peluang Peningkatan Penerbitan Buku Sastra Bali Modern. Jurnal Kajian Bali, 9(2), 475-498. https://doi.org/10.24843/JKB.2019.v09.i02.p10

Pramono. (2008). Pemetaan Kritik Teks dan Kritik Sastra Terhadap Kaba: Sebuah Penelitian Awal. Jurnal Ilmu Budaya, 5(1), 1-22. https://doi.org/10.31849/jib.v5i1.882.

Salam, A. \& Saeful A. (2015). Strategi dan Legitimasi Komunitas Sastra di Yogyakarta: Kajian Sosiologi Sastra Pierre Bourdieu. Widyaparwa, 43(1), 2538. https://doi.org/10.26499/wdprw.v43i1.103

Sudarmoko. (2016). Republishing Folktales: Their Audiences, Readers, and Influence in Modern Indonesian Literature. Kritika Kultura, 27, 125-150. https://journals.ateneo.edu/ojs/index.php/kk/article/view/KK2016.02708 
Sunarti, S. (2013). Kelisanan dan Keberaksaraan dalam Suart Kabar TerbitanAwal Minangkabau (1859-1940-an). Jakarta: Kepustakaan Populer Gramedia bekerja sama dengan École française d'Extrême-Orient, KITLV dan Fadli Zon Library.

Zamzuri, A. (2015). Bengkel Sastra Balai Bahasa DIY Dalam Perspektif Sosiologi Pierre Bourdieu. Paramasastra, 290-303. https://journal.unesa.ac.id/index.php/paramasastra/article/view/1534

Zurmailis \& Faruk. 2017. Doksa, Kekerasan Simbolik dan Habitus yang Ditumpangi dalam Konstruksi Kebudayaan di Dewan Kesenian Jakarta. Adabiyyat, 1(1), 44-72. https://doi.org/10.14421/ajbs.2017.01103. 
